\title{
Steer Clear
}

Helga Peter

Marburg, Deutschland

\section{Definition}

Fahrsimulator.

Siehe \ „Leistungstests und Fahrtauglichkeitsprüfung“. 